\title{
Endometrial carcinoma with yolk sac tumor-like differentiation and elevated serum $\beta$-hCG: a case report and literature review
}

This article was published in the following Dove Press journal:

OncoTargets and Therapy

23 October 2013

Number of times this article has been viewed

\author{
Mingliang $\mathrm{Ji}^{1}$ \\ Yan Lu' \\ Lina Guo ${ }^{2}$ \\ Fengzhi Feng' \\ Xirun Wan' \\ Yang Xiang' \\ 'Department of Obstetrics and \\ Gynecology, ${ }^{2}$ Department of \\ Pathology, Peking Union Medical \\ College Hospital, Beijing, \\ People's Republic of China
}

Correspondence: Yang Xiang

Department of Obstetrics and Gynecology, Peking Union Medical College Hospital, No I Shuaifuyuan, Wangfujing, DongCheng District, Beijing 100730, People's Republic of China

Tel +86 I35 II 050222

Email xiangy@pumch.cn

\begin{abstract}
Endometrial carcinoma with a germ cell tumor component is a rare event. Here we report a uterine neoplasm with a unique combination of endometrioid adenocarcinoma and mixed germ cell malignant elements. A 28 -year-old woman with abnormal vaginal bleeding, an abdominal mass, and elevated alfa-fetoprotein and beta-human chorionic gonadotropin ( $\beta$-hCG) levels had a history of biopsy of an omental mass and chemotherapy in another hospital one month before her referral to our department. Histologic examination of the mass removed from the omentum revealed an endometrioid adenocarcinoma with yolk sac tumor-like differentiation. Total abdominal hysterectomy, bilateral salpingo-oophorectomy, infracolic omentectomy, and removal of metastatic disease were then undertaken at our hospital. Postoperative chemotherapy was given. Eight months postoperatively, serum alfa-fetoprotein and $\beta$-hCG rose again. Cases with primary yolk sac tumors of the endometrium or endometrial carcinoma with trophoblastic differentiation in the literature were reviewed.
\end{abstract}

Keywords: endometrial carcinoma, yolk sac tumor, trophoblastic differentiation

\section{Introduction}

Yolk sac tumors, also known as endodermal sinus tumors, and trophoblastic neoplasms are both malignant germ cell tumors. Producing alfa-fetoprotein and human chorionic gonadotropin (hCG), respectively, yolk sac tumors and trophoblastic neoplasms are strongly suggested by elevated serum alfa-fetoprotein and hCG levels.

Primary yolk sac tumors of the endometrium are extremely rare; to our knowledge, only nine cases have been reported in the literature, ${ }^{1-9}$ among which only two cases are in coexistence with endometrial carcinomas. Endometrial carcinomas with trophoblastic differentiation are also very rare, with only 17 cases in the literature. ${ }^{10-24}$ Despite being uncommon, such cases have a distinct prognosis from pure endometrial adenocarcinoma. These two groups of cases do not share an intersection set. However, we report a case of endometrial carcinoma with yolk sac tumor-like differentiation, as well as elevated serum level of the beta-subunit of hCG ( $\beta-h C G)$, which suggests trophoblastic differentiation although there is a lack of histologic evidence. A dramatic postoperative reduction of $\beta$-hCG further supports the existence of a trophoblastic component.

\section{Case report}

A 28-year-old, nulligravid, married Chinese woman presented in December 2010 with a 14-month history of abnormal vaginal bleeding. The patient had been on barrier contraception, and to her knowledge had never been pregnant. Past medical history 
included epilepsy and hypothyroidism due to thyroidectomy. In October 2010, a diagnostic curettage specimen revealed endometrial adenocarcinoma with glandular squamous metaplasia, and an exploratory laparotomy was performed in a local hospital. A large omental mass and diffuse miliary nodules in the pelvic peritoneum made exposure of the surgical field difficult, so biopsy of the mass and peritoneum only was performed and histologic examination showed endometrial adenocarcinoma with yolk sac tumor-like differentiation. Chemotherapy, including intravenous paclitaxel $120 \mathrm{mg}$, adriamycin $60 \mathrm{mg}$, and intraperitoneal cisplatin $150 \mathrm{mg}$ for one course, was administered at the local hospital. The patient was then referred to our hospital, where laboratory tests showed serum alfa-fetoprotein level of $1,522 \mathrm{ng} / \mathrm{mL}$ (normal value $\leq 20 \mathrm{ng} / \mathrm{mL}$ ), $\beta$-hCG $518.9 \mathrm{mIU} / \mathrm{mL}$ (normal value $\leq 5 \mathrm{mIU} / \mathrm{mL}$, chemiluminescent technology, Advia Centaur $^{\mathrm{TM}}$ XP immunoassay system, Siemens, Erlangen, Germany), and CA $125129 \mathrm{U} / \mathrm{mL}$ (normal value $\leq 35 \mathrm{U} / \mathrm{mL}$ ). A chest computed tomography scan was negative.

The patient underwent cytoreductive surgery, including total abdominal hysterectomy, bilateral salpingooophorectomy with pelvic lymphadenectomy, omentectomy, appendectomy, partial sigmoidectomy with anastomosis, and resection of abdominal and pelvic metastases, without residual visible metastases. The uterus measured $10 \times 8 \times 5 \mathrm{~cm}$ and the cavity was filled with a cauliflower-like tumor measuring $6 \times 3 \times 2.5 \mathrm{~cm}$ and containing areas of ulceration (see Figure 1). This solid tumor had a grayish-white cut surface and moderate texture. Histopathologic examination of the uterine tumor revealed well to moderately differentiated

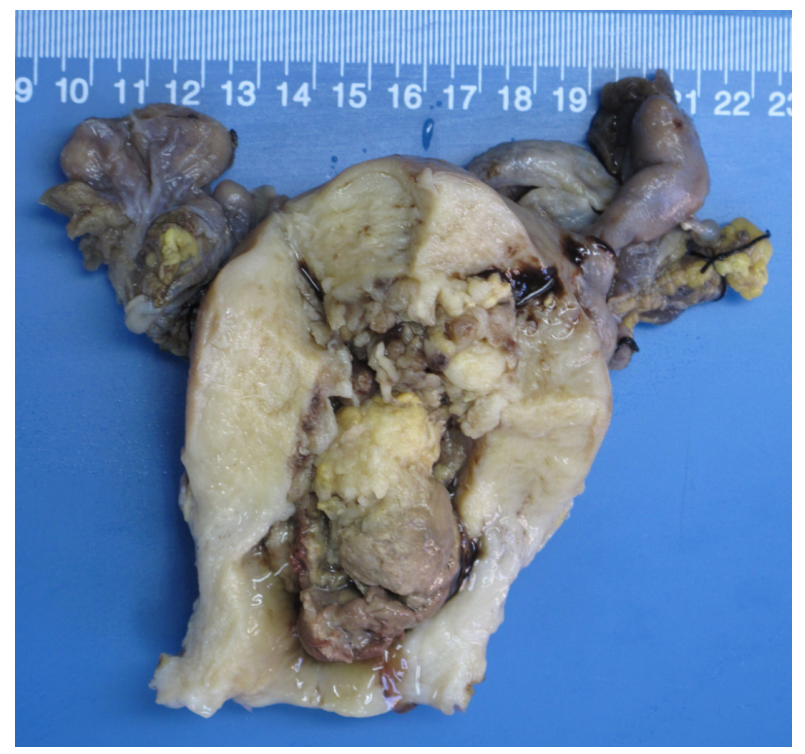

Figure I Gross image of the uterus and tumor.

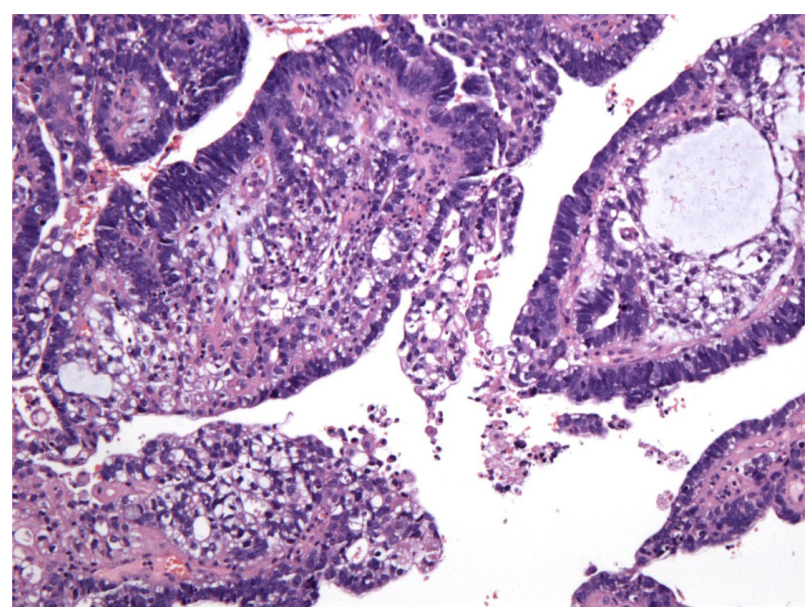

Figure 2 Mixed components: a close transition from the endometrial adenocarcinoma to the yolk sac tumor areas (hematoxylin and eosin, 100×).

endometrial adenocarcinoma with yolk sac tumor-like differentiation intraendometrially, with a close transition between the two components (Figure 2). No trophoblastic component was found. The metastases were identical to the primary lesion on histology. The myometrium, cervix, appendix, bilateral adnexa, and iliac lymph nodes were negative for tumor. Periodic-acid Schiff stain was positive in yolk sac tumor cells. Immunohistochemical analysis revealed that both endometrial adenocarcinoma and yolk sac tumor components were positive for AE1/AE3. The yolk sac tumor component was strongly positive for alfa-fetoprotein, while the endometrial adenocarcinoma was relatively negative (Figure 3). The endometrial adenocarcinoma component was positive for EMA, CA125, and CK7, suggesting epithelial neoplasms. There was focal positive staining for $\mathrm{p} 53$. Estrogen receptor and progesterone receptor status were both negative, as were hCG and $\beta$-hCG.

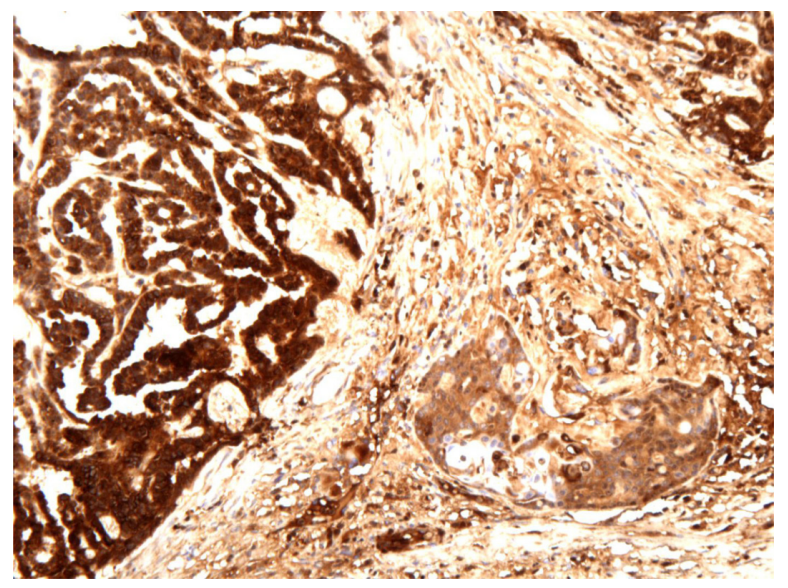

Figure $3 \mathrm{Immunohistochemical} \mathrm{staining} \mathrm{results} \mathrm{for} \mathrm{alfa-fetoprotein} \mathrm{confirm} \mathrm{the}$ existence of two components of endometrial adenocarcinoma and yolk sac tumor. 


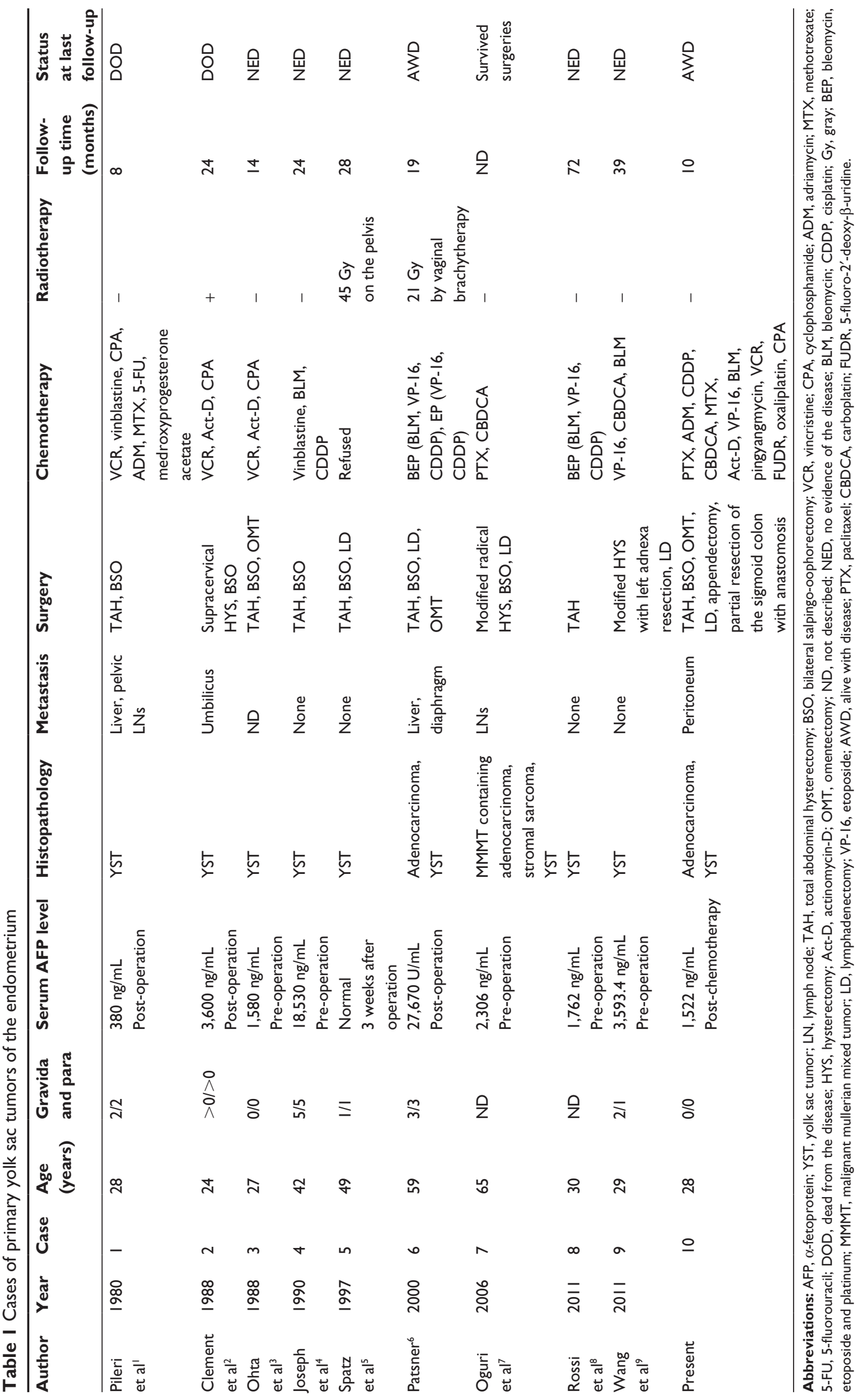


Two days after surgery, serum alfa-fetoprotein and $\beta$-hCG levels decreased dramatically to $166.4 \mathrm{ng} / \mathrm{mL}$ and $13.7 \mathrm{mIU} / \mathrm{mL}$, respectively, and the CA125 level dropped into the normal range. Six courses of intravenous chemotherapy with paclitaxel $175 \mathrm{mg} / \mathrm{m}^{2}$ per day followed by carboplatin for an area under the concentration-time curve of $5 \mathrm{mg} / \mathrm{mL}$ per minute were administered every 21 days.
Serum alfa-fetoprotein dropped to the normal range after three courses, while $\beta$-hCG fluctuated in the range of $5-20 \mathrm{mIU} / \mathrm{mL}$ despite two additional courses of chemotherapy with etoposide, methotrexate, actinomycin $\mathrm{D}$, etoposide, and cisplatin ${ }^{25}$ followed by two courses with bleomycin, etoposide, and platinum. ${ }^{26}$ The persistent slightly elevated $\beta$-hCG was considered due to abnormal pituitary feedback, so chemotherapy

Table 2 Cases of endometrial neoplasm with trophoblastic differentiation

\begin{tabular}{|c|c|c|c|c|c|c|}
\hline Author & Year & Case & Age (years) & $\begin{array}{l}\text { Gravida and } \\
\text { para }\end{array}$ & $\begin{array}{l}\text { Serum (S)/urinary (U) } \\
\text { hCG level }\end{array}$ & $\begin{array}{l}\text { Concurrent endometrial } \\
\text { tumor }\end{array}$ \\
\hline Civantos and Rywlin ${ }^{10}$ & 1972 & I & 87 & $3 / 2$ & $\begin{array}{l}\text { U hCG: I,000 IU/24 hours } \\
\text { Preradiotherapy }\end{array}$ & SPC \\
\hline Savage et al" & 1987 & 2 & 70 & $\mathrm{I} / \mathrm{I}$ & Unmeasured & AD \\
\hline \multirow[t]{3}{*}{ Pesce et $\mathrm{al}^{12}$} & 1991 & 3 & 78 & $\mathrm{ND} / 0$ & $\begin{array}{l}\text { S } \beta \text {-hCG: } 19,500 \mathrm{mIU} / \mathrm{mL} \\
\text { Pre-chemotherapy }\end{array}$ & AD \\
\hline & & 4 & 48 & $5 / \mathrm{ND}$ & $\begin{array}{l}\mathrm{S} \beta \text {-hCG: } 3,050 \mathrm{mIU} / \mathrm{mL} \\
\text { Pre-operation }\end{array}$ & $A D$ \\
\hline & & 5 & 63 & Multi/multi & $\begin{array}{l}\text { U hCG: } 1,00,000 \mathrm{IU} / 24 \text { hours } \\
\text { Persistently until death }\end{array}$ & $A D$ \\
\hline Kalir et $\mathrm{al}^{13}$ & 1995 & 6 & 83 & $0 / 0$ & $\begin{array}{l}\text { S hCG: }>1,00,000 \mathrm{mlU} / \mathrm{mL} \\
\text { Pre-operation }\end{array}$ & $A D$ \\
\hline Black et $\mathrm{al}^{14}$ & 1998 & 7 & 88 & $\mathrm{ND} / \mathrm{I}$ & $\begin{array}{l}\text { S hCG: } 85 \text { I IU/L (estimated } \\
\text { postoperatively) }\end{array}$ & $\begin{array}{l}\text { Clear cell AD; focal } \\
\text { endometrioid differentiation }\end{array}$ \\
\hline Bradley et $\mathrm{al}^{15}$ & 1998 & 8 & 68 & $4 / 4$ & $\begin{array}{l}\mathrm{S} \beta \text {-hCG: } 95 \mathrm{mlU} / \mathrm{mL} \\
\text { Pre-operation }\end{array}$ & $\begin{array}{l}\text { AD; focal squamous and } \\
\text { clear cell differentiation }\end{array}$ \\
\hline Tunc et $a^{16}$ & 1998 & 9 & 54 & $6 / 6$ & $\begin{array}{l}\text { S } \beta \text {-hCG: } 5,514 \mathrm{mlU} / \mathrm{mL} \\
\text { Pre-operation }\end{array}$ & AD \\
\hline Khuu et al ${ }^{17}$ & 2000 & 10 & 71 & $0 / 0$ & $\begin{array}{l}\mathrm{S} \beta \text {-hCG: } 283 \mathrm{mIU} / \mathrm{mL} \\
\text { Post-operation }\end{array}$ & $\begin{array}{l}\text { (Anterior) AD; (posterior) } \\
\text { MMMT containing AD }\end{array}$ \\
\hline Nguyen et al ${ }^{18}$ & 2000 & II & 34 & $0 / 0$ & $\begin{array}{l}\text { S } \beta \text {-hCG: } 32,000 \mathrm{mlU} / \mathrm{mL} \\
\text { Pre-operation }\end{array}$ & $\begin{array}{l}\text { MMMT containing AD, focal clear } \\
\text { cell and serous differentiation }\end{array}$ \\
\hline Le Bret et al ${ }^{19}$ & 2005 & 12 & 54 & $4 / 1$ & $\begin{array}{l}\text { S } \beta \text {-hCG: I3,87,205 IU/L } \\
\text { Pre-operation }\end{array}$ & $A D$ \\
\hline Horn et $\mathrm{al}^{20}$ & 2006 & 13 & 61 & $3 / 3$ & $\begin{array}{l}\text { S } \beta \text {-hCG: } 2,25,000 \text { IU/L } \\
\text { Post-operation }\end{array}$ & SPC \\
\hline Akbulut et $\mathrm{al}^{21}$ & 2008 & 14 & 42 & ND/ND & $\begin{array}{l}\text { S } \beta \text {-hCG: I.74 mlU/mL } \\
\text { Post-operation }\end{array}$ & $A D$ \\
\hline Yamada et $\mathrm{al}^{22}$ & 2008 & 15 & 58 & $\mathrm{I} / \mathrm{I}$ & $\begin{array}{l}\text { S } \beta \text {-hCG: } 38 \text { ng/mL } \\
\text { Post-operation }\end{array}$ & $A D$ \\
\hline Olson et $\mathrm{al}^{23}$ & 2011 & 16 & 68 & $6 / 4$ & ND & $A D$ \\
\hline Wakahashi et $\mathrm{al}^{24}$ & 2012 & 17 & 85 & $5 / 2$ & $\begin{array}{l}\text { S } \beta \text {-hCG: } 8.0 \mathrm{ng} / \mathrm{mL} \\
\text { (normal, }<0.1 \mathrm{ng} / \mathrm{mL} \text { ) } \\
\text { Pre-operation }\end{array}$ & $\begin{array}{l}\text { AD with squamous } \\
\text { differentiation }\end{array}$ \\
\hline Present & & 18 & 28 & $0 / 0$ & $\begin{array}{l}\mathrm{S} \beta \text {-hCG: } 518.9 \mathrm{mIU} / \mathrm{mL} \\
\text { Post-chemotherapy }\end{array}$ & $A D, Y S T$ \\
\hline
\end{tabular}

Abbreviations: hCG, human chorionic gonadotropin; SPC, serous papillary carcinoma; ND, not described; AD, adenocarcinoma; TAH, total abdominal hysterectomy; BSO, bilateral salpingo-oophorectomy; 5-FU, 5-fluorouracil; ADM, adriamycin; DOD, dead of the disease; LN, lymph node; CDDP, cisplatin; BLM, bleomycin; VCR, vincristine; MTX, methotrexate; VP-I6, etoposide; AWD, alive with the disease; Gy, gray; UTI, urinary tract infection; OMT, omentectomy; LD, lymphadenectomy; PTX, paclitaxel; CBDCA, carboplatin; NED, no evidence of the disease; Act-D, actinomycin-D; MMMT, malignant mullerian mixed tumor; CPA, cyclophosphamide; THP, herarubicin; YST, yolk sac tumor; FUDR, 5-fluoro-2'-deoxy- $\beta$-uridine. 
was stopped. Unfortunately, $\beta$-hCG and alfa-fetoprotein rose again 2-3 months later. Despite salvage chemotherapy with two cycles of floxuridine, dactinomycin, etoposide, and vincristine, ${ }^{27}$ serum alfa-fetoprotein reached $311.1 \mathrm{ng} / \mathrm{mL}$ and $\beta$-hCG reached 2,716.5 mIU/mL. After the final course with oxaliplatin $200 \mathrm{mg}$ and cyclophosphamide $800 \mathrm{mg}$, the patient abandoned further treatment and was lost to follow-up.

\section{Discussion}

Here we report a case of endometrial carcinoma with yolk sac tumor-like differentiation as well as elevated serum $\beta$-hCG level suggesting trophoblastic differentiation although there was a lack of histologic evidence. Yolk sac tumors and trophoblastic neoplasms are both malignant germ cell tumors, and when found simultaneously, mixed germ cell

\begin{tabular}{|c|c|c|c|c|c|}
\hline Metastasis & Surgery & Chemotherapy & Radiotherapy & $\begin{array}{l}\text { Follow-up } \\
\text { time (mo) }\end{array}$ & $\begin{array}{l}\text { Status at last } \\
\text { follow-up }\end{array}$ \\
\hline ND & - & - & + & ND & ND \\
\hline $\begin{array}{l}\text { Liver, kidneys, lungs, } \\
\text { brain, peritoneum }\end{array}$ & TAH, BSO & $\begin{array}{l}\text { Medroxyprogesterone, 5-FU, } \\
\text { ADM, megestrol acetate }\end{array}$ & + & 14 & DOD \\
\hline LNs & - & CDDP, BLM, oncovin (VCR) & - & 1.5 & DOD \\
\hline Lungs & TAH & MTX; VP-16, BLM, CDDP & - & ND & ND \\
\hline $\begin{array}{l}\text { Peritoneum, lungs, } \\
\text { liver }\end{array}$ & TAH, BSO & - & - & 14 & DOD \\
\hline Lungs & TAH, BSO & CDDP, VP-I6 & - & 1 & AWD \\
\hline None & TAH, BSO & - & 50.4 Gy on pelvis & 18 & Died from UTI \\
\hline LNs & TAH, BSO, OMT, LD & $\begin{array}{l}\text { Megestrol acetate; PTX, } \\
\text { CBDCA }\end{array}$ & - & 16 & NED \\
\hline Retroperitoneal mass & TAH, BSO & $\begin{array}{l}\text { MTX, CPA, Act-D, VP-16, } \\
\text { folinic acid }\end{array}$ & - & 24 & DOD \\
\hline- & TAH, BSO, LD & - & - & 8 & NED \\
\hline Lungs, brain, LNs & TAH, BSO, OMT, LD & $\begin{array}{l}\text { PEB (BLM, VP-16, CDDP), } \\
\text { EMA/CO (VP-16, MTX, Act-D, } \\
\text { CPA, VCR), CDDP, PTX }\end{array}$ & 44 Gy on brain & 7 & DOD \\
\hline Lungs & Colpohysterectomy, LD & VP-16, CDDP & 45 Gy on pelvis & 18 & NED \\
\hline Lungs & TAH, BSO, LD & $\begin{array}{l}\text { MTX, EMA/CO (VP-16, MTX, } \\
\text { Act-D, CPA, VCR) }\end{array}$ & - & 3 & DOD \\
\hline None & $\begin{array}{l}\text { TAH, BSO, appendectomy, } \\
\text { OMT, LD }\end{array}$ & - & - & 6 & NED \\
\hline Vaginal cuff & TAH, BSO, LD & $\begin{array}{l}\text { CTP (CBDCA, THP, CPA); } \\
\text { EMA/CO (VP-16, MTX, } \\
\text { Act-D, CPA, VCR) }\end{array}$ & - & 50 & NED \\
\hline Axillary LN & TAH, BSO & ND & ND & ND & ND \\
\hline $\begin{array}{l}\text { Peritoneum; } \\
\text { Douglas pouch }\end{array}$ & TAH, BSO & - & - & 5 & AWD \\
\hline Peritoneum & $\begin{array}{l}\text { TAH, BSO, OMT, LD, } \\
\text { appendectomy, partial } \\
\text { sigmoidectomy with } \\
\text { anastomosis }\end{array}$ & $\begin{array}{l}\text { PTX, ADM, CDDP, CBDCA, } \\
\text { MTX, Act-D, VP-16, BLM, } \\
\text { pingyangmycin, VCR, FUDR, } \\
\text { oxaliplatin, CPA }\end{array}$ & - & 10 & AWD \\
\hline
\end{tabular}


tumor is diagnosed, and usually within the gonads. ${ }^{28}$ Primary extragonadal concurrent yolk sac tumors and trophoblastic neoplasms are extremely rare, but have been known to occur in the thyroid, ${ }^{29}$ Barrett's esophagus, ${ }^{30}$ and in gastric ${ }^{31}$ and colon carcinoma. ${ }^{32}$ The histogenetic mechanism for primary extragonadal germ cell tumors remains controversial. ${ }^{7}$ The close transition from the endometrioid adenocarcinoma to the yolk sac tumor areas (Figure 2) in the present case supports an origin involving aberrant differentiation of somatic cells. Mixed tumors with a germ cell tumor component usually manifest as tumors in corresponding organs; for instance the present case had a medical history of abnormal vaginal bleeding of 14 months' duration, which unfortunately was not paid enough attention. Unlike typical endometrial carcinoma, she was young and presented with peritoneal metastasis without myometrial infiltration or lymphadenopathy. Hence, histopathologic examination of specimens from diagnostic curettage and exploratory laparotomy are of great clinical importance in such circumstances.

Primary yolk sac tumors of the endometrium are extremely rare. To our knowledge, only nine cases have been reported in the literature (Table 1), ${ }^{1-9}$ among which seven cases are pure yolk sac tumors and only two cases ${ }^{6,7}$ are in coexistence with endometrial carcinoma. All the patients presented with a medical history of abnormal vaginal bleeding and elevated serum alfa-fetoprotein levels before or immediately after surgery. Extragonadal germ cell tumors are diagnosed histopathologically. Yolk sac tumor presents variously under the microscope, and occasionally there is confusion in differentiating a microcystic or endodermal sinus-like structure from a clear cell uterine carcinoma and a papillary structure from uterine serous papillary carcinoma. In addition to morphologic differences, immunohistochemical staining is helpful. Yolk sac tumors are strongly positive for alfa-fetoprotein. In addition, serum alfa-fetoprotein determinations are important in the diagnosis of yolk sac tumors and monitoring metastasis or recurrence after therapy. Most of the reviewed cases experienced a reduction in serum alfa-fetoprotein after surgery and adjuvant therapy, as did our patient.

Yolk sac tumors usually occur in the gonads of young people. ${ }^{1}$ In the previously published literature, cases with pure yolk sac tumors are younger (age range 27-49 years, mean 32.7 years) than those with mixed tumors (age range 59-65 years, mean 62 years). In the seven patients with pure yolk sac tumors, five $\mathrm{e}^{3-5,8,9}$ presented no metastasis (or not described) and no evidence of disease at last follow-up more than one year (6 year at most) after diagnosis. Among these five, two cases $^{8,9}$ had a unilateral ovary or bilateral ovaries retained after surgery because they were young women, indicating a more favorable prognosis. In contrast with these cases, those with endometrial neoplasms with yolk sac tumor-like differentiation were all postmenopausal women, and presented with early metastasis to the liver, diaphragm, or abdominal lymph nodes. This second group of cases tends to have a worse prognosis. The case reported by Patsner ${ }^{6}$ used a potential carcinogen (tamoxifen for prior breast cancer) and the tumor metastasized 19 months after diagnosis despite two surgeries and administration of combined chemotherapy and radiotherapy. The different components of the tumor have a transition zone, so erroneous differentiation of somatic cells was proposed as the histogenetic mechanism of the tumor cells, ie, the yolk sac tumor cells were derived from dedifferentiation or retrodifferentiation of somatic endometrial (tumor) cells. The present case had concurrent endometrioid adenocarcinoma and yolk sac tumor components in both primary and metastatic tumors, and metastasis occurred early. Despite multiple courses and regimens of chemotherapy, alfa-fetoprotein rose again 8 months postoperatively. These clinical and pathologic features strongly resemble the cases in the latter group mentioned above, except for the very young age of 28 years.

The present self-reported nulligravid case had elevated serum $\beta$-hCG level during her entire medical course, but no trophoblastic differentiation was observed under the microscope. Grenache et $\mathrm{al}^{33}$ reported a similar case of endometrial adenocarcinoma without trophoblastic differentiation and with an elevated serum free $\beta$-hCG and no evidence of pregnancy. In their case, endometrial adenocarcinoma cells showed hCG immunoreactivity and were believed to produce free $\beta$-hCG. In the present case, however, the decrease in $\beta$-hCG following surgery and chemotherapy excluded the possibility of phantom $\beta$-hCG or $\beta$-hCG elevation associated with the testing method used. Given that the tumor cells seen were negative for hCG and $\beta$-hCG by immunohistochemical analysis, the authors believe that a trophoblastic component did exist, and the negative histology findings might be due to the chemotherapy before admission, and failure to get the positive section in pathological slice-making.

Endometrial neoplasms with trophoblastic differentiation are also very rare, with only 17 cases reported in the literature (Table 2). ${ }^{10-24}$ These 17 patients are relatively older (age range 34-88 years, mean 65.4 years). All cases, including the present one, presented with abnormal genital bleeding except for one without description, and elevated serum or urinary 
$\beta$-hCG before or shortly after therapy, with a median serum $\beta$-hCG level of 3,050 mIU/mL, except one case with normal serum $\beta$-hCG first measured after histologic diagnosis of surgical specimens. ${ }^{21}$ Most of the cases had been pregnant, so gestational trophoblastic neoplasms could not be excluded completely. However, Olson et $\mathrm{al}^{23}$ reported a case with clonal evolution from endometrioid carcinoma to trophoblastic tumor proven by morphologic and molecular genetic analysis, suggesting great utility of this method. Endometrioid adenocarcinoma is the most frequently reported histologic type in the predominant component of the concurrent tumor, occurring in 12 of the reported cases, with serous papillary carcinoma in two cases and clear cell carcinoma in one case. Khuu et $\mathrm{al}^{17}$ and Nguyen et $\mathrm{al}^{18}$ reported two cases of malignant Müllerian mixed tumor containing an endometrioid adenocarcinomatous component with trophoblastic differentiation as well as a sarcomatous component. The median follow-up duration was 11 months, and at last follow-up, seven cases had died (follow-up 1.5-24 months), two were alive with disease ( 1 and 5 months), and five with relatively low initial serum $\beta$-hCG (median $283 \mathrm{mIU} / \mathrm{mL}$ ) were alive without evidence of disease (6-50 months).

Horn et $\mathrm{al}^{20}$ proposed two prognostically relevant types of endometrial carcinoma containing trophoblastic differentiation. One type presents with only a few syncytiotrophoblastic-like giant cells and the other with a notable extension of trophoblastic differentiation, resembling a choriocarcinoma. The latter type is associated with strongly elevated $\beta$-hCG, early metastasis, and often a fatal course. The present case presented with no observable trophoblastic cells and a moderately elevated $\beta-\mathrm{hCG}$ at admission, suggesting a more favorable prognosis according to Horn's proposition. However, despite the rapid decrease in $\beta$-hCG after hysterectomy, it remained slightly and persistently elevated and finally rose again to $2,716.5 \mathrm{mIU} / \mathrm{mL}$. The patient was lost to follow-up 10 months after diagnosis, implying an unfavorable outcome.

\section{Conclusion}

To the author's knowledge, endometrial adenocarcinoma associated with both yolk sac tumor-like differentiation and an elevated serum $\beta$-hCG level has never been reported in the literature. We present such a case and share our experiences in treatment. Unlike the reviewed cases of endometrial adenocarcinoma with a single germ cell tumor component, our patient was very young and presented with peritoneal metastasis early but without myometrial infiltration or lymphadenopathy. The histology of the metastases was identical to that of the primary tumor, with mixed components. The cytoreductive surgery and chemotherapy tend to show an effective immediate efficacy. The choice of subsequent chemotherapies was based on the major tumor component at each follow-up. However, the disease progressed rapidly and was resistant to salvage chemotherapy. Because medical history, gynecologic examination, and imaging results contribute little to early recognition of extragonadal germ cell tumors, histopathologic examination of specimens from diagnostic curettage and exploratory laparotomy are of great clinical significance in such conditions. Once diagnosed, serum alfa-fetoprotein and $\beta$-hCG determinations are important in monitoring metastasis or recurrence. The histogenetic mechanism is unclear, and further investigations with molecular genetic analysis are required.

\section{Disclosure}

The authors report no conflicts of interest in this work.

\section{References}

1. Pileri S, Martinelli G, Serra L, Bazzocchi F. Endodermal sinus tumor arising in the endometrium. Obstet Gynecol. 1980;56(3):391-396.

2. Clement PB, Young RH, Scully RE. Extraovarian pelvic yolk sac tumors. Cancer. 1988;62(3):620-626.

3. Ohta M, Sakakibara K, Mizuno K, et al. Successful treatment of primary endodermal sinus tumor of the endometrium. Gynecol Oncol. 1988;31(2):357-364.

4. Joseph MG, Fellows FG, Hearn SA. Primary endodermal sinus tumor of the endometrium. A clinicopathologic, immunocytochemical, and ultrastructural study. Cancer. 1990;65(2):297-302.

5. Spatz A, Bouron D, Pautier P, Castaigne D, Duvillard P. Primary yolk sac tumor of the endometrium: a case report and review of the literature. Gynecol Oncol. 1998;70(2):285-288.

6. Patsner B. Primary endodermal sinus tumor of the endometrium presenting as "recurrent" endometrial adenocarcinoma. Gynecol Oncol. 2001;80(1):93-95.

7. Oguri H, Sumitomo R, Maeda N, Fukaya T, Moriki T. Primary yolk sac tumor concomitant with carcinosarcoma originating from the endometrium: case report. Gynecol Oncol. 2006;103(1):368-371.

8. Rossi R, Stacchiotti D, Bernardini MG, Calvieri G, Lo Voi R. Primary yolk sac tumor of the endometrium: a case report and review of the literature. Am J Obstet Gynecol. 2011;204(4):e3-e4.

9. Wang C, Li G, Xi L, Gu M, Ma D. Primary yolk sac tumor of the endometrium. Int J Gynaecol Obstet. 2011;114(3):291-293.

10. Civantos F, Rywlin AM. Carcinomas with trophoblastic differentiation and secretion of chorionic gonadotrophins. Cancer. 1972;29(3): 789-798.

11. Savage J, Subby W, Okagaki T. Adenocarcinoma of the endometrium with trophoblastic differentiation and metastases as choriocarcinoma: a case report. Gynecol Oncol. 1987;26(2):257-262.

12. Pesce C, Merino MJ, Chambers JT, Nogales F. Endometrial carcinoma with trophoblastic differentiation. An aggressive form of uterine cancer. Cancer. 1991;68(8):1799-1802.

13. Kalir T, Seijo L, Deligdisch L, Cohen C. Endometrial adenocarcinoma with choriocarcinomatous differentiation in an elderly virginal woman Int J Gynecol Pathol. 1995;14(3):266-269.

14. Black K, Sykes P, Ostor AG. Trophoblastic differentiation in an endometrial carcinoma. Aust N Z J Obstet Gynaecol. 1998;38(4):472-473. 
15. Bradley CS, Benjamin I, Wheeler JE, Rubin SC. Endometrial adenocarcinoma with trophoblastic differentiation. Gynecol Oncol. 1998;69(1):74-77.

16. Tunc M, Simsek T, Trak B, Uner M. Endometrium adenocarcinoma with choriocarcinomatous differentiation: a case report. Eur $J$ Gynaecol Oncol. 1998;19(5):489-491.

17. Khuu HM, Crisco CP, Kilgore L, Rodgers WH, Conner MG. Carcinosarcoma of the uterus associated with a nongestational choriocarcinoma. South Med J. 2000;93(2):226-228.

18. Nguyen CP, Levi AW, Montz FJ, Bristow RE. Coexistent choriocarcinoma and malignant mixed mesodermal tumor of the uterus. Gynecol Oncol. 2000;79(3):499-503.

19. Le Bret T, Tranbaloc P, Benbunan JL, Salet-Lizee D, Villet R. [Endometrial choriocarcinoma in peri-menopausal women]. J Gynecol Obstet Biol Reprod (Paris). 2005;34(1 Pt 1):85-89. French.

20. Horn LC, Hanel C, Bartholdt E, Dietel J. Serous carcinoma of the endometrium with choriocarcinomatous differentiation: a case report and review of the literature indicate the existence of 2 prognostically relevant tumor types. Int J Gynecol Pathol. 2006;25(3):247-251.

21. Akbulut M, Tosun H, Soysal ME, Oztekin O. Endometrioid carcinoma of the endometrium with choriocarcinomatous differentiation: a case report and review of the literature. Arch Gynecol Obstet. 2008;278(1): 79-84.

22. Yamada T, Mori H, Kanemura M, Ohmichi M, Shibayama Y. Endometrial carcinoma with choriocarcinomatous differentiation: a case report and review of the literature. Gynecol Oncol. 2009;113(2):291-294.

23. Olson MT, Gocke CD, Giuntoli RL 2nd, Shih Ie M. Evolution of a trophoblastic tumor from an endometrioid carcinoma - a morphological and molecular analysis. Int J Gynecol Pathol. 2011;30(2):117-120.

24. Wakahashi S, Sudo T, Nakagawa E, et al. Endometrioid adenocarcinoma with high-grade transformation with serous and choriocarcinomatous differentiation - a case report. J Cancer. 2012;3:14-18.
25. Behtash N, Karimi Zarchi M. Placental site trophoblastic tumor. J Cancer Res Clin Oncol. 2008;134(1):1-6.

26. Alazzam M, Tidy J, Osborne R, Coleman R, Hancock BW, Lawrie TA. Chemotherapy for resistant or recurrent gestational trophoblastic neoplasia. Cochrane Database Syst Rev. 2012;12:CD008891.

27. Feng F, Xiang Y, Wan X, Geng S, Wang T. Salvage combination chemotherapy with floxuridine, dactinomycin, etoposide, and vincristine (FAEV) for patients with relapsed/chemoresistant gestational trophoblastic neoplasia. Ann Oncol. 2011;22(7):1588-1594.

28. Zhao S, Kato N, Endoh Y, Jin Z, Ajioka Y, Motoyama T. Ovarian gonadoblastoma with mixed germ cell tumor in a woman with 46, XX karyotype and successful pregnancies. Pathol Int. 2000;50(4): 332-335.

29. Wierzbicka-Chmiel J, Chroszcz M, Slomian G, et al. [Mixed germ cells tumour primarily located in the thyroid - a case report]. Endokrynol Pol. 2012;63(5):388-390. Russian.

30. Wasan HS, Schofield JB, Krausz T, Sikora K, Waxman J. Combined choriocarcinoma and yolk sac tumor arising in Barrett's esophagus. Cancer. 1994;73(3):514-517.

31. Satake N, Chikakiyo M, Yagi T, Suzuki Y, Hirose T. Gastric cancer with choriocarcinoma and yolk sac tumor components: case report. Pathol Int. 2011;61(3):156-160.

32. Kawahara M, Takada A, Tachibana A, et al. Germ cell tumor of the colon with an adenocarcinomatous component. Int J Clin Oncol. 2009;14(6):537-540.

33. Grenache DG, Moller KA, Groben PM. Endometrial adenocarcinoma associated with elevated serum concentrations of the free beta subunit of human chorionic gonadotropin. Am J Clin Pathol. 2004;121(5):748-753.
OncoTargets and Therapy

\section{Publish your work in this journal}

OncoTargets and Therapy is an international, peer-reviewed, open access journal focusing on the pathological basis of all cancers, potential targets for therapy and treatment protocols employed to improve the management of cancer patients. The journal also focuses on the impact of management programs and new therapeutic agents and protocols on

\section{Dovepress}

patient perspectives such as quality of life, adherence and satisfaction The manuscript management system is completely online and includes a very quick and fair peer-review system, which is all easy to use. Visit http://www.dovepress.com/testimonials.php to read real quotes from published authors. 